\title{
BOUNDARY VALUE PROBLEMS FOR NONLINEAR FRACTIONAL DIFFERENTIAL EQUATIONS AND INCLUSIONS WITH NONLOCAL AND INTEGRAL BOUNDARY CONDITIONS
}

\author{
SOTIRIS K. NTOUYAS
}

Abstract. In this paper, we study a class of boundary value problems of nonlinear fractional differential equations and inclusions with nonlocal and integral boundary conditions. Some new existence and uniqueness results are obtained by using a variety of fixed point theorems. Examples are given to illustrate the results.

Mathematics subject classification (2010): 26A33, 34A08, 34A60.

Keywords and phrases: Fractional differential equations, fractional differential inclusions, nonlocal conditions, integral boundary conditions, existence, fixed point theorems.

\section{REFERENCES}

[1] R. P. Agarwal, B. Andrade, C. Cuevas, Weighted pseudo-almost periodic solutions of a class of semilinear fractional differential equations, Nonlinear Anal. Real World Appl. 11 (2010), 3532-3554.

[2] R.P. Agarwal, V. Lakshmikantham, J. J. Nieto, On the concept of solution for fractional differential equations with uncertainty, Nonlinear Anal. 72 (2010), 2859-2862.

[3] R.P. AgARWAL, Y. ZHOU, Y. HE, Existence of fractional neutral functional differential equations, Comput. Math. Appl. 59 (2010), 1095-1100.

[4] B. Ahmad, S. Sivasundaram, On four-point nonlocal boundary value problems of nonlinear integro-differential equations of fractional order, Appl. Math. Comput. 217 (2010), 480-487.

[5] B. AHMAD, Existence of solutions for irregular boundary value problems of nonlinear fractional differential equations, Appl. Math. Lett. 23 (2010), 390-394.

[6] B. AHMAD, Existence of solutions for fractional differential equations of order $q \in(2,3]$ with antiperiodic boundary conditions, J. Appl. Math. Comput. 34 (2010), 385-391.

[7] B. AhmAD, On nonlocal boundary value problems for nonlinear integro-differential equations of arbitrary fractional order, Results Math. 63 (2013), 183-194.

[8] B. AHMAD, A. ALSAEDI, Existence and uniqueness of solutions for coupled systems of higher order nonlinear fractional differential equations, Fixed Point Theory Appl. 2010 (2010), Article ID 364560, $17 \mathrm{pp}$.

[9] B. Ahmad, S.K. NTOUYAs, A. ALs AEDi, New existence results for nonlinear fractional differential equations with three-point integral boundary conditions, Adv. Differ. Equ. 2011, Article ID 107384, $11 \mathrm{pp}$.

[10] B. AhmAD, J.J. NiETo, Existence results for nonlinear boundary value problems of fractional integrodifferential equations with integral boundary conditions, Bound. Value Probl. 2009, Art. ID 708576, $11 \mathrm{pp}$.

[11] B. AHMAD, J.J. NiETO, Existence results for a coupled system of nonlinear fractional differential equations with three-point boundary conditions, Comput. Math. Appl. 58 (2009), 1838-1843.

[12] Z.B. BAI, On positive solutions of a nonlocal fractional boundary value problem, Nonlinear Anal. 72 (2010), 916-924.

[13] K. Balachandran, J.J. Trujillo, The nonlocal Cauchy problem for nonlinear fractional integrodifferential equations in Banach spaces, Nonlinear Anal. 72 (2010), 4587-4593.

[14] M. BENCHOHRA, S. HAMANI, S.K. NTOUYAS, Boundary value problems for differential equations with fractional order, Surv. Math. Appl. 3 (2008), 1-12. 
[15] M. Benchohra, S. Hamani, S.K. NTOUYAS, Boundary value problems for differential equations with fractional order and nonlocal conditions, Nonlinear Anal. 71 (2009), 2391-2396.

[16] A.V. BITSADZE, On the Theory of Nonlocal Boundary Value Problems, Dokl. Akad. Nauk SSSR 277 (1984), 17-19.

[17] A. Bressan, G. Colombo, Extensions and selections of maps with decomposable values, Studia Math. 90 (1988), 69-86.

[18] L. BySZEWS Ki, V.LAKShmikANTham, Theorem about the existence and uniqueness of a solution of a nonlocal abstract Cauchy problem in a Banach space, Appl. Anal. 40 (1991), 11-19.

[19] L. B YSZEWS KI, Theorems about existence and uniqueness of solutions of a semilinear evolution nonlocal Cauchy problem, J. Math. Anal. Appl. 162 (1991), 494-505.

[20] L. BYSZEWSKI, Existence and uniqueness of mild and classical solutions of semilinear functionaldifferential evolution nonlocal Cauchy problem, Selected problems of mathematics, 50th Anniv. Cracow Univ. Technol. Anniv., Issue 6, Cracow Univ. Technol., Krakow, 1995, pp. 25-33.

[21] K. Deimling, Multivalued Differential Equations, Walter De Gruyter, Berlin-New York, 1992.

[22] M. FRIGON, Théorèmes d'existence de solutions d'inclusions différentielles, Topological Methods in Differential Equations and Inclusions (edited by A. Granas and M. Frigon), NATO ASI Series C, Vol. 472, Kluwer Acad. Publ., Dordrecht, 1995, 51-87.

[23] Sh. Hu, N. Papageorgiou, Handbook of Multivalued Analysis, Theory I, Kluwer, Dordrecht, 1997.

[24] A. Granas And J. Dugundu, Fixed Point Theory, Springer-Verlag, New York, 2005.

[25] A.A. Kilbas, H.M. SRivastaVa, J.J. Trujillo, Theory and Applications of Fractional Differential Equations, North-Holland Mathematics Studies, 204. Elsevier Science B.V., Amsterdam, 2006.

[26] A. LASOTA AND Z. OpIAL, An application of the Kakutani-Ky Fan theorem in the theory of ordinary differential equations, Bull. Acad. Polon. Sci. Ser. Sci. Math. Astronom. Phys. 13 (1965), 781-786.

[27] M.P. LAZAREvić, A.M. Spasić, Finite-time stability analysis of fractional order time-delay systems: Gronwall's approach, Math. Comput. Model. 49 (2009), 475-481.

[28] J.J. NIETO, Maximum principles for fractional differential equations derived from Mittag-Leffler functions, Appl. Math. Lett. 23 (2010), 1248-1251.

[29] D. O'REgAn, Fixed-point theory for the sum of two operators, Appl. Math. Lett. 9 (1996), 1-8.

[30] W. V. Petryshyn AND P.M. FitzPATRIC, A degree theory, fixed point theoremsand mapping theorems for multivalued noncompact maps, Trans. Amer. Math. Soc. 194 (1974), 1-25.

[31] I. Podlubny, Fractional Differential Equations, Academic Press, San Diego, 1999.

[32] J. Sabatier, O.P. Agrawal, J.A.T. Machado (Eds.), Advances in Fractional Calculus: Theoretical Developments and Applications in Physics and Engineering, Springer, Dordrecht, 2007.

[33] S. G. Samko, A.A. Kilbas, O.I. Marichev, Fractional Integrals and Derivatives, Theory and Applications, Gordon and Breach, Yverdon, 1993.

[34] Z. WEI, Q. LI, J. CHE, Initial value problems for fractional differential equations involving RiemannLiouville sequential fractional derivative, J. Math. Anal. Appl. 367 (2010), 260-272.

[35] S. Q. ZHANG, Positive solutions to singular boundary value problem for nonlinear fractional differential equation, Comput. Math. Appl. 59 (2010), 1300-1309.

[36] W. ZHONG, W. Lin, Nonlocal and multiple-point boundary value problem for fractional differential equations, Comput. Math. Appl. 39 (2010), 1345-1351. 